\title{
KONAKLAMA VE YİYECEK-İÇECEK İŞLETMELERİ MUHASEBE ÇALIŞANLARININ YETERLILIKLERINII BELİRLEMEYE YÖNELIKK GÖRGÜL BİR ARAŞTIRMA
}

\author{
$* * *$ \\ AN EMPIRICAL STUDY ACCOMMODATION AND FOOD- BEVERAGE \\ BUSINESSES ON DETERMINING THE PROFICIENCIES OF ACCOUNTING \\ STAFF
}

\author{
Yrd. Doç. Dr. Murat KARAHAN \\ Gaziantep Üniversitesi \\ İktisadi ve İdari Bilimler Fakültesi \\ İşletme Bölümü \\ karahan@gantep.edu.tr
}

Öğr. Gör. Metin SÜRME

Gaziantep Üniversitesi

Turizm ve Otelcilik Meslek Yüksekokulu Seyahat-Turizm ve Eğlence Hizmetleri Bölümü surmemetin@gmail.com

Öğr. Gör. Meryem GÜL

Osmaniye Korkut Ata Üniversitesi Düziçi Meslek Yüksekokulu

Yönetim ve Organizasyon Bölümü meryemgul@osmaniye.edu.tr

\begin{abstract}
Öz
Gerçekleştirilen bu araştırmanın temel amacı, konaklama ve yiyecek-içecek işletmeleri muhasebe çalışanlarının yeterlilik düzeyinin belirlenmesi olarak belirlenmiştir. Bu amacı gerçekleştirmek üzere Antalya ve Gaziantep illerinde faaliyet gösteren 116 konaklama ve yiyecek-içecek işletmeleri yöneticilerinden kolayda örnekleme yöntemi ile veri toplanmıştır. Araştırma sonucunda konaklama ve yiyecek-içecek işletmeleri muhasebe çalışanlarının tam olarak yeterli olmadiğı görülmüştür. Gerçekleştirilen bu araştırmada, "raporlama ve analiz yeterliliği, teorik bilgi yeterliliği ve turizm muhasebesi yeterliliğ $i$ ” olmak üzere 3 faktör olduğu görülmüştür. Bu üç faktörün ortalamalarına bakıldığında; turizm muhasebesi yeterliliğinin en yüksek ortalamaya sahip olduğu görülmüştür.
\end{abstract}

Anahtar Kelimeler: Konaklama İşletmeleri, Yiyecek-İ̧̧ecek İsletmeleri, Muhasebe, Yeterlilik.

\begin{abstract}
The aim of this research carried out, accommodation and food and beverage business is defined as thedetermination of theadequacy of thelevel of theaccountingstaff. For this purpose the data was collected by Antalya and Gaziantep sampling over 116 people in the tourism business operating in the province to perform. As a result of the accommodation and food and beverage enterprises accounting staff has been shownto were not fully adequate. In this research conducted, it is seen that there are 3 factors, namely "reporting and analysis proficiency, theoretical knowledg eproficiency and tourism accounting proficiency". When we look at the average of these three factors; Tourism accounting proficiency has the highest average.
\end{abstract}

Keywords: Accommodation Businesses, Food and Beverage Businesses, Accounting, proficiency 


\section{GİRIŞ}

Konaklama ve yiyecek içecek işletmelerinin temel kuruluş amacı kar elde etmektir. Muhasebe departmanı da bu kârın nasıl elde edildiğini ve bu süreçte işletmenin kaynak ve varlık yapısının nasıl elde edildiğini açıklamaktadır. Bununla birlikte Konaklama ve yiyecek içecek işletmeleri muhasebe departmanının "Nakit ödemelerin yapılması, muhasebe kayıtlarının düzenlenmesi, çek-senet düzenleme ve takibi, banka hesaplarının kontrolü, adisyon kontrolleri, günlük nakit akış tablosu, tahsilatların yapılması, aylık faaliyet raporları, fatura düzenlenmesi, ödenmezlerin kontrolü, kiracı alacaklarının takibi, döviz ve kredi kartı işlemleri, bütçe hazırlanması" gibi temel işlevleri bulunmaktadır (Kozak, 2012).

Muhasebe kayıtları, konaklama ve yiyecek içecek işletmeleri yöneticilerine işletme hakkında genel bir bakış açısı kazandırmaktadır. Bununla birlikte işletme yöneticileri yönetsel kararları vermeden önce muhasebe kayıtlarından yararlanmaktadır. Çünkü muhasebe kayıtları objektif ve güvenilir ilkelere dayanmaktadır. Dolayısıyla böyle bilgi ile donatılmış işletmelerin gelecekleri hakkında uygun finansal ve stratejik kararları alması daha kolay olacaktır (McManus, 2013: 142). Bu sebeple konaklama ve yiyecek-içecek işletmelerinde çalışan muhasebe çalışanların yeterliliği önem taşımaktadır. Aksi bir durumda sistem amaca uygun hizmet edemeyecektir. Başka bir ifade ile muhasebe sistemini yeterli eğitim almamış çalışanlarla yürütmek durumunda kalan işletmeler bilgi sağlamada büyük sorunlarla karşılaşabilirler. Bununla beraber Parker (2002), öğrencilerin gelecekteki iş taleplerini karşılayabilmek için üniversitede verilen muhasebe eğitiminin yeterliliği konusunda endişe duymaktadır. Benzer bir araştırmada Jackson ve Chapman (2012), muhasebe mezunlarının, hızla gelişen ekonomik, teknolojik ve sosyal çevreye değer katmak için gerekli yeterliliklerle donatılmış olması gerektiğinin altını çizmektedir. Tüm bu sebepler göz önüne alındığında konaklama ve yiyecek-içecek işletmeleri muhasebe çalışanlarının yeterliliğinin araştırılmasının önemi kolayca görülmektedir. Bu kapsamda gerçekleştirilen bu araştırmada, konaklama ve yiyecek-içecek işletmeleri muhasebe çalışanlarının yeterlilik düzeyleri ortaya konmuştur.

Bu çalışma dört bölümden oluşmaktadır. İlk bölüm giriş bölümüdür. Bu bölümde konaklama ve yiyecek içecek işletmeleri ile ilgili bilgilere yer verilmiştir. İkinci bölümde literatürdeki çalışmalardan bahsedilmiştir. Üçüncü bölümde araştırmanın amacı, kapsamı yöntemi açıklanmıştır. Dördüncü bölümde; kullanılan analiz yöntemleri ve araştırma sonuçlarına yer verilmiştir. Son olarak da çalışmadan elde edilen bulgular ve öneriler sonuç bölümünde ele alınmıştır.

\section{LITERATÜR TARAMASI}

Teknolojinin gelişmesi ile birlikte muhasebe meslek mensuplarının da gelişmelere uyum sağlaması gerekmektedir (Biyan, 2012: 107). Başka bir ifade ile muhasebe uygulamaları, muhasebe kuramına ilişkin mantığın oluşturulması ve geliştirilmesi için zorunludur (Yıldız ve Durak, 2011: 37). Bununla birlikte muhasebe uygulamaları ile muhasebe eğitimi arasında eskiden beri süre gelen "muhasebe açığı" giderek artmaktadır. Başka bir ifade ile gelişen teknoloji, muhasebe mesleği üyelerine yeni görev ve sorumluluklar yüklemektedir (Kozak, 2012: 169). Söz konusu bu muhasebe açığının kapatılabilmesi için öncelikle muhasebe ders programlarının değiştirilmesi, öğrencilerin değişmelere ayak uydurabilmesi ve bunları anlamalarını sağlayacak firsatların tanınması gerekmektedir (Gençtürk ve Çarıkçı, 2008: 211).

İşletmelerin muhasebe çalışanlarından en önemli beklentileri raporlama ve analiz yeterliliğidir (Barth, 2008; Sunder, 2010; Dalğar vd., 2011; Hatunoğlu vd., 2013; Karakaya Demirkutlu, 2014; Özsözgün Çalışkan, 2014). Özsözgün Çalışkan (2014)'a göre geleneksel raporlama sistemi yalnızca ticari faaliyetlerin finansal sonuçlarıyla ilgilidir. Ancak yaşanan gelişmelerle birlikte işletmelerin, ticari faaliyetlerin bir bütün olarak ekonomik, sosyal ve çevresel etkilerini gösteren yeni bir raporlama sistemine gereksinimi duyduğunu belirtmektedir. Dolayısıyla bu yeni gereklilik, muhasebe çalışanlarının raporlama sistemi oluştururken yeni sorumluluklar üstlenmesi gerektiğini belirtmektedir.

Konaklama ve yiyecek-içecek işletmelerinde emek yoğun özelliğinden dolayı muhasebe çalışanlarının turizm muhasebesi yeterliliğine sahip olmasını gerekli kılmaktadır. $\mathrm{Bu}$ yüzden konaklama ve yiyecek-içecek işletmelerinin muhasebe işlemlerini en iyi şekilde yerine getirebilecek, 
hizmet sektöründe önem arz eden muhasebe verilerini en iyi şekilde yorumlayarak stratejik kararlar verebilecek nitelikli personellerin yetiştirilmesi önem taşımaktadır.

Teorik bilgi yeterliliği, teknik ve idari süreçlerden geçen muhasebe pratiklerinin rasyonelleşmesine ve meşruluğunun anlaşılmasına yardımcı olmaktadır. Buna göre Demir (2012), muhasebe alanında teorik ve uygulamalı bilgi ve becerilerin kazandırılmasının muhasebe eğitiminin temel amacı olduğunu belirtmektedir. Başka bir ifade ile muhasebe eğitiminin amacına ulaşabilmesi için, öğrencinin muhasebe teorisi ile ilgili bilgilerin yanı sıra uygulamaya yönelik bilgilerle de sürekli güncellenmesi gerekmektedir.

Konuya ilişkin literatür incelendiğinde muhasebe eğitiminin şirketlerin beklentilerini tam olarak karşılamadığı sonucu ortaya konmuştur (Yardım, 2009; Kutluk, vd., 2012; Hatunoğlu ve Kı1lı, 2014; Yücenurşen, 2016). Söz konusu bu çalışmaların ana hatları ise aşağıda gösterilmektedir.

- Kutluk vd. (2012), muhasebe eğitiminin şirketlerin beklentilerini karşılamadığı sonucunu tespit etmişlerdir. Yardım (2009), ise ortaöğretim düzeyinde verilen muhasebe eğitiminden öğrencilerin ve işverenlerin memnuniyetlerinin belirlenmesi amaciyla bir araştırma gerçekleştirmiş ve bu araştırma sonucunda muhasebe öğrencilerinin muhasebe dışı envanter işlemlerini, muhasebe içi envanter işlemlerini ve işletme maliyet kayıtları konularında yetersiz oldukları ortaya konmuştur.

- Ünal (2013), bankacıların muhasebe eğitiminden beklentileri tespit etmeye yönelik bir araştırma gerçekleştirmiş ve bu araştırma sonucunda muhasebe derslerinin yeterli olmadığ 1 sonucunu ortaya koymuşlardır.

- Altın (2009), Türkiye'de verilen genel muhasebe ve şirketler muhasebesi eğitiminin Aksaray'daki işletme beklentilerini karşılamakla birlikte, maliyet muhasebesi, yönetim muhasebesi, muhasebe denetimi, mali tablolar analizi, bilgisayarl muhasebe, enflasyon muhasebesi, uluslararası muhasebe ve Türk vergi sistemi gibi derslerin verilme düzeylerinin işletme beklentilerini karşılamamakta olduğu sonucunu tespit etmişlerdir.

- Duman vd. (2013), işletmelerin muhasebe eğitiminden beklentileri ve memnuniyet düzeyleri üzerinde bir araştırma gerçekleştirmiş ve bu araştırma sonucunda işletmelerin muhasebe eğitiminden beklentilerinin tam olarak karşılanamadığı sonucu ortaya konmuştur.

- Ünal ve Doğanay (2009) ise, muhasebe grubu dersleri; müfredat içerisinde ağırlığı yeterli olmakla birlikte kurumların ihtiyaçlarını tam anlamıyla karşılayamamakta olduğunu belirtmişlerdir. Benzer bir araştırmada Yürekli ve Gönen (2015), muhasebe eğitimin, meslek mensuplarının ihtiyaç duyduğu ara eleman ihtiyacını karşılamaktan uzak olduğunu belirtmişlerdir.

- Penafort ve Ahmed (1997) ise, Malezya'da 500 muhasebe mesleğine ilişkin iş ilanını incelemiş ve bu araştırma sonucunda akademik yeterlilik, bilgisayar okuryazarlığının yanı sıra çalışma deneyimi, liderlik, motivasyon, yenilikçilik becerileri, güçlü olmak gibi ek niteliklere sahip özelliklere sahip olmaları gerektiği ortaya konmuştur.

- Yücenurşen vd., (2016)'nin gerçekleştirdiği araştırma ise tüm bu araştırma sonuçlarını destekler niteliktedir. Buna göre Yücenurşen vd., (2016) Türkiye'de yapılmış muhasebe eğitimi ve kalite kapsamında süreli yayınları incelemiş ve araştırma sonucunda Türkiye'de verilen muhasebe eğitiminin beklentileri karşılamadığ 1 sonucunu ortaya koymuştur. Bununla birlikte muhasebe eğitiminde kalitenin artırılması gerektiğinin altını çizmektedir.

- İlgili literatürde üniversitelerde verilen muhasebe eğitiminin işletmelerin beklentilerini tam olarak karşılamadığı görülmüştür. Bu durum ise doğal olarak işletmelerin karlılığını ve verimliliğini olumsuz yönde etkilemektedir.

Literatürde, konaklama ve yiyecek-içecek işletmeleri muhasebe çalışanlarının yeterliliklerini araştıran sınırlı araştırmanın olduğu görülmüştür. Bu kapsamda gerçekleştirilen bu araştırmada konaklama ve yiyecek-içecek işletmeleri muhasebe çalışanlarının yeterlilik düzeyleri üzerine 
odaklanılmıştır. Dolayısıyla gerçekleştirilen araştırmanın bu yönüyle ilgili literatüre konu eksikliğinin giderilmesi açısından katkı sunması düşünülmektedir.

\section{MATERYAL VE YÖNTEM}

Konaklama ve yiyecek-içecek işletmeleri muhasebe çalışanlarının yeterlilik düzeyinin belirlenmesi amaciyla kolayda örnekleme yöntemi ile belirlenen ve Gaziantep ve Antalya illerinde faaliyet gösteren işletme yöneticilerine anket uygulanmıştır.

Anket iki bölümden oluşmaktadır. Buna göre ilk bölümde, işletmelerinin özelliklerini belirlemeye ilişkin sorulara yer verilmiştir. Bu sorular; işletmenin hukuki yapısı, hangi sektörde faaliyet gösterdiği, muhasebe kayıtlarını nerede tuttuğu, hizmet içi eğitime sahip olup olmadığı ve muhasebe departmanında kaç kişinin çalıştığı ile ilgili sorulara yer verilmiştir. Anketin ikinci bölümünde ise konaklama ve yiyecek-içecek işletmeleri muhasebe çalışanlarının yeterlilik düzeyini ölçmek amacıyla Uyar ve Yelgen (2012) tarafından geliştirilen ölçek ve sorulardan faydalanılmıştır. Bu sorular 5'li Liket tipidir. Çalışma kapsamında toplanan veriler kolayda örnekleme yöntemi ile tespit edilen toplam 116 yöneticiden elde edilmiştir.

\subsection{Araştırmanın Modeli ve Hipotezleri}

Konaklama ve yiyecek-içecek işletmeleri muhasebe çalışanlarının yeterlilik düzeyi ilişkisi teorik olarak modellenmiştir. Şekil l'de araştırmanın teorik modeli gösterilmektedir.

Şekil 1: Araştırmanın Teorik Modeli

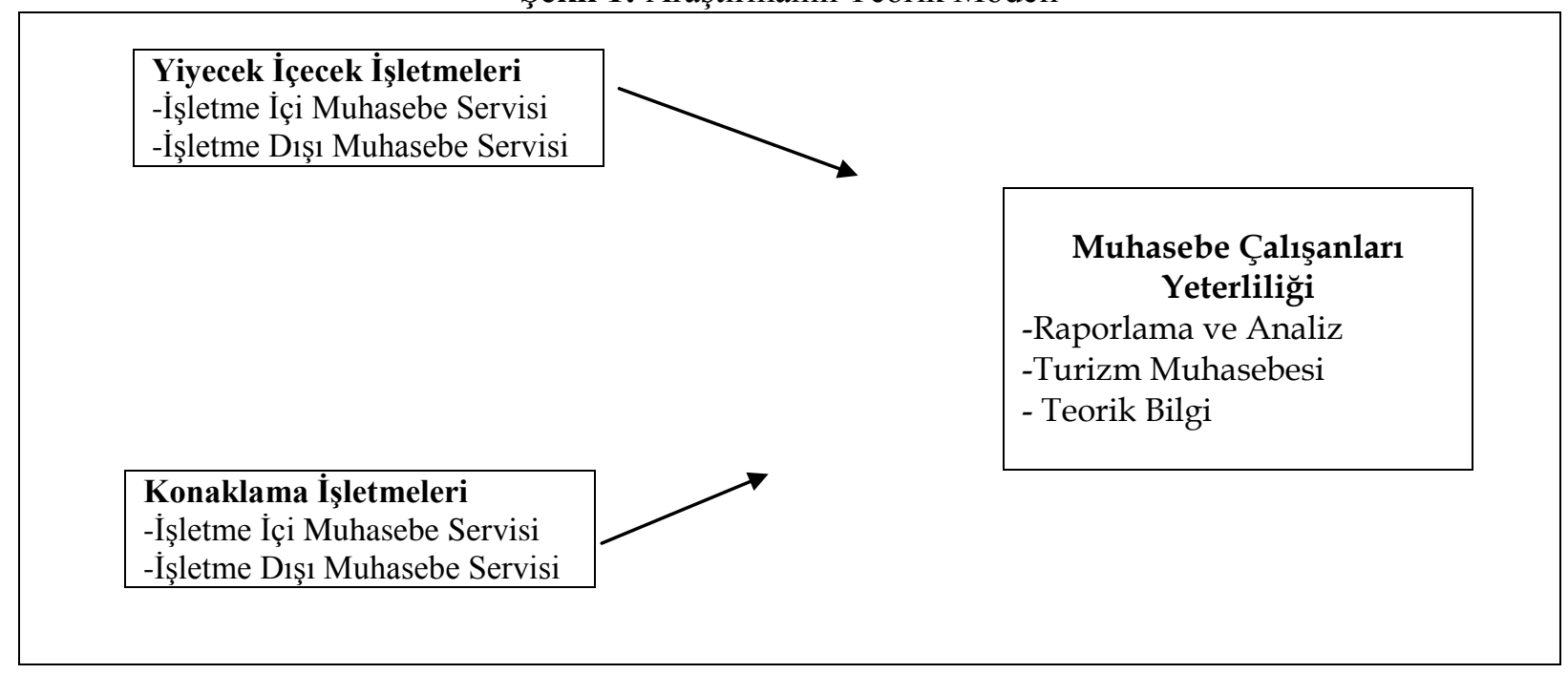

Araştırmada konaklama ve yiyecek-içecek işletmeleri muhasebe çalışanlarının yeterlilik düzeyinin belirlenmesi ile ilgili geliştirilen hipotezler şu şekilde sıralanmıştır:

$\mathbf{H}_{1}$ : Konaklama ve yiyecek-içecek işletmeleri muhasebe çalışanlarının raporlama ve analiz yeterliliği farkl1lık göstermektedir.

$\mathbf{H}_{2}$ : Konaklama ve yiyecek-içecek işletmeleri muhasebe çalışanlarının turizm muhasebesi yeterliliği farkl1lık göstermektedir.

$\mathbf{H}_{3}$ : Konaklama ve yiyecek-içecek işletmeleri muhasebe çalışanlarının teorik bilgi yeterliliği farkl11ık göstermektedir.

$\mathbf{H}_{4}$ : Muhasebe kayıtlarının tutulduğu yere göre muhasebe çalışanlarının raporlama ve analiz yeterliliği farkl1lık göstermektedir. 
$\mathbf{H}_{5}$ : Muhasebe kayıtlarının tutulduğu yere göre muhasebe çalışanlarının turizm muhasebesi yeterliliği farklılık göstermektedir.

$\mathbf{H}_{6}$ : Muhasebe kayıtlarının tutulduğu yere göre muhasebe çalışanlarının teorik bilgi yeterliliği farkl111k göstermektedir.

\section{ARAȘTIRMANIN BULGULARI}

$\mathrm{Bu}$ bölümde araştırmanın amacı kapsamında elde edilen bulguların analizi yer almaktadır. Araştırmanın bulgular kısmı 3 başlıkta gösterilmektedir. Buna göre ilk kısımda araştırmaya katılan turizm işletmelerine ilişkin tanıtıcı bilgiler, ikinci bölümde yapılan faktör analizine ilişkin bulgular, üçüncü bölümde ise konaklama ve yiyecek-içecek işletmeleri muhasebe çalışanlarının yeterlilik düzeyinin belirlenmesine yönelik bulgular gösterilmiştir.

\subsection{Araştırmaya Katılan Konaklama ve Yiyecek-İçecek İşletmelerine İliş̧kin Tanıtıcı Bilgiler}

Araştırmaya katılan turizm işletmelerinin; hangi sektörde faaliyette bulunduğu, muhasebe kayıtlarının nerede tutulduğu, muhasebe eğitiminde hizmet içi eğitime sahip olup olmadığı ve muhasebe departmanında kaç kişi çalıştığı konularındaki özelliklerini belirlemeye yönelik 4 adet soru yöneltilmiş ve frekans ve yüzde değerleri hesaplanmıştır. Elde edilen sonuçlar Tablo 1'de gösterilmiştir.

Tablo 1. Tanımlayıc İstatistikler

\begin{tabular}{lll}
\hline İşletmenin Hukuki Yapısı & Frekans (n) & Yüzde (\%) \\
\hline Tek kişi işletmesi & 76 & 65,5 \\
Adi şirket & 10 & 8,6 \\
Limitet şirket & 20 & 17,2 \\
Anonim şirket & 10 & 8,6 \\
\hline Muhasebe Departmanında Çalışan Kişi Sayısı & Frekans (n) & Yüzde (\%) \\
\hline 0-3 kişi & 99 & 85,3 \\
4-7 kişi & 17 & 14,7 \\
\hline İşletmenin faaliyette bulunduğu sektör & Frekans (n) & Yüzde (\%) \\
\hline Konaklama & 51 & 44,0 \\
Yiyecek-içecek & 65 & 56,0 \\
\hline Muhasebe Kayıtlarının Tutulduğu Yer & Frekans (n) & Yüzde (\%) \\
\hline İşletme içi muhasebe servisinde & 48 & 41,4 \\
İşletme dışı muhasebe servisinde & 68 & 58,6 \\
\hline Muhasebe Eğitiminde Hizmet İçi Ĕgitime Sahip Olma Durumu & Frekans (n) & Yüzde (\%) \\
\hline Evet & 33 & 28,4 \\
Hayır & 83 & 71,6 \\
\hline
\end{tabular}

Tablo 3'e göre işletmelerin \%44'ü konaklama, \%56's1 ise yiyecek-içecek sektöründe faaliyet göstermektedir. Bununla birlikte işletmelerin \% 41,4'ü muhasebe kayıtlarını işletme içi muhasebe servisinde, \%58,6'sının ise işletme dışı muhasebe servisinde tutmaktadır. Diğer taraftan işletmelerin $\% 28,4$ 'ü muhasebe eğitiminde hizmet içi eğitime sahip ve \%71,6'sının ise muhasebe eğitiminde hizmet içi eğitime sahip olmadığı görülmüştür.

\subsection{Faktör Analizi}

Araştırma hipotezlerini test etmeden önce farklı kavramları ölçmek için kullanılan sorular üzerinde açımlayıcı faktör analizi yapılmıştır. Faktör analizi yapılmazdan önce, verilerin faktör analizine uygunluğunu görmek amaciyla Barlett küresellik testi yapılmış ve KMO değeri hesap edilmiştir. Sonuçta Barlett testi anlamlı çıkmış (Ki-Kare $=956,466 \mathrm{sd}=190, \mathrm{p}=0,000)$ ve KMO değeri ise 0,793 olarak hesaplanmıştır. Sorular arasında beşinci ve onuncu sorunun binişik madde olduğu 
görülmüş ve faktör analizinden bu soru çıkarılmıştır. Bu sonuçlar verilerin faktör analizi için uygun olduğunu ortaya koymuştur. Bunun üzerine faktör analizi gerçekleştirilmiştir. Analiz yöntemi olarak Temel Bileșenler Analizi yöntemi kullanılmış ve faktör sayısını belirlemede ise hesaplanan özdeğerin 1 'den büyük olması kriteri kullanılmıştır. Analiz sonucunda veriler 3 faktöre yüklenmiştir. Faktörler tarafından açıklanan toplam varyansın ise $\% 50,070$ olduğu gözlemlenmiştir. $\mathrm{Bu}$ da analiz sonucu oluşan faktörlerin verileri yeterince temsil ettiğini göstermektedir. Değișkenlerin faktörlere yüklenmeleri Tablo 4'te gösterilmiştir. Yorumlamada kolaylık olması amaciyla faktör yüklemeleri Varimax yöntemi ile döndürülmüş ve faktör yüklenmesi 0,40 'ın altında olan faktör yüklenmeleri gösterilmemiştir.

Faktörlere yüklenen soru gruplarının güvenirliliklerini ölçmek için her soru grubu üzerinde Cronbach alfa katsayısı hesaplanmıştır. Hesaplanan alfa değerleri Tablo 2'de gösterilmiştir. Güvenirlik değerleri yeterli bulunan soru gruplarının, daha sonraki analizlerde kullanılmak üzere ortalamaları alınmış ve yeni değişkenler oluşturulmuştur. Oluşturulan değişkenler Raporlama ve analiz yeterliliği (1), Teorik bilgi yeterliliği (2), Turizm muhasebesi yeterliliği (3), olarak adlandırılmıştır. Değişkenlere ait tanımlayıcı istatistikler Tablo 3 'te verilmiştir.

Tablo 2. Faktör Yüklenmeleri ve Cronbach's Alfa Değerleri

\begin{tabular}{llll}
\hline Faktörler & $\mathbf{1}$ & $\mathbf{2}$ & $\mathbf{3}$ \\
\hline RAY1 & 0,752 & & \\
RAY2 & 0,726 & & \\
RAY3 & 0,695 & & \\
RAY4 & 0,683 & & \\
RAY5 & 0,670 & & \\
RAY6 & 0,656 & & \\
RAY7 & 0,652 & & \\
RAY8 & 0,624 & & \\
RAY9 & 0,622 & & \\
RAY10 & 0,485 & 0,756 & \\
TMY1 & & 0,754 & \\
TMY2 & & 0,655 & \\
TMY3 & & 0,622 & \\
TMY4 & & 0,488 & 0,771 \\
TMY5 & & 0,473 & 0,722 \\
TMY6 & & & 0,663 \\
TBY1 & & & 0,750 \\
TBY2 & & \\
TBY3 & & 0,735 & \\
Cronbach's Alfa & 0,874 & & \\
\hline
\end{tabular}

Tablo 3. Faktör İstatistikleri

\begin{tabular}{llll}
\hline \multicolumn{1}{c}{ Faktörler } & Ortalama & & Std. Sapma \\
\hline Raporlama ve Analiz Yeterliliği (RAY) & 2,98 &, 88 & \\
\hline Turizm Muhasebesi Yeterliliği (TMY) & 3,43 &, 81 & \\
\hline Teorik Bilgi Yeterliliği (TBY) & 3,27 &, 02 & \\
\hline
\end{tabular}

Konaklama ve yiyecek-içecek işletmeleri muhasebe çalışanlarının yeterlilikleri açısından bir farklılık olup olmadığını görmek amacıyla bağımsız değişkenler $t$ testleri yapılmıştır. Test sonuçları Tablo 4’te gösterilmiştir. 
Tablo 4. Konaklama Ve Yiyecek-İçecek İşletmeleri Muhasebe Çalışanlarının Yeterliliklerinin Karşılaştırılması

\begin{tabular}{|c|c|c|c|c|c|c|}
\hline Bağımlı Değişkenler & Bağımsız Değişkenler & $\mathbf{n}$ & Ortalama & $\mathbf{t}$ & df & $\mathbf{p}$ \\
\hline \multirow{2}{*}{ Raporlama ve Analiz Yeterliliği (RAY) } & Konaklama & 51 & 3,00 & \multirow{2}{*}{0,224} & \multirow{2}{*}{114} & \multirow{2}{*}{0,823} \\
\hline & Yiyecek-İçecek & 65 & 2,96 & & & \\
\hline \multirow{2}{*}{ Turizm Muhasebesi Yeterliliği (TMY) } & Konaklama & 51 & 3,32 & \multirow{2}{*}{$-1,279$} & \multirow{2}{*}{114} & \multirow{2}{*}{0,204} \\
\hline & Yiyecek-İçecek & 65 & 3,52 & & & \\
\hline \multirow[b]{2}{*}{ Teorik Bilgi Yeterliliği (TBY) } & Konaklama & 51 & 3,31 & \multirow[b]{2}{*}{0,403} & \multirow{2}{*}{114} & \multirow[b]{2}{*}{0,688} \\
\hline & Yiyecek-İçecek & 65 & 3,23 & & & \\
\hline
\end{tabular}

Yapılan analizler sonucunda konaklama ve yiyecek-içecek işletmeleri muhasebe çalışanları arasında "raporlama ve analiz yeterliliği, turizm muhasebesi yeterliliği ve teorik bilgi yeterliliği" açısından anlamlı bir farklılık görülmemiştir ( $p>0,05)$. Bu bilgiler doğrultusunda $\mathrm{H}_{1}, \mathrm{H}_{2}$ ve $\mathrm{H}_{3}$ hipotezi reddedilmiştir.

Tablo 5: Muhasebe Kayıtları Tutulduğu Yere Göre Muhasebe Çalışanlarının Yeterliliklerinin Karşılaştırılması

\begin{tabular}{|c|c|c|c|c|c|c|}
\hline Bağımlı Değişkenler & Bağımsız Değișkenler & $\mathbf{n}$ & Ort. & $\mathbf{t}$ & df & $\mathbf{p}$ \\
\hline & İşletme içinde, muhasebe servisinde & 48 & 2,92 & \multirow[b]{2}{*}{$-0,527$} & \multirow[b]{2}{*}{114} & \multirow[b]{2}{*}{0,599} \\
\hline $\begin{array}{l}\text { Raporlama ve } \\
\text { Yeterliliği (RAY) }\end{array}$ & $\begin{array}{l}\text { Żşletme dişında, serbest muhasebeci mali } \\
\text { müşavirin bürosunda }\end{array}$ & 68 & 3,01 & & & \\
\hline \multirow{2}{*}{$\begin{array}{l}\text { Turizm Muhasebesi Yeterliliği } \\
(\mathrm{TMY})\end{array}$} & İşletme içinde, muhasebe servisinde & 48 & 3,37 & \multirow[b]{2}{*}{$-0,710$} & \multirow[b]{2}{*}{114} & \multirow[b]{2}{*}{0,479} \\
\hline & $\begin{array}{l}\text { İşletme dişında, serbest muhasebeci mali } \\
\text { müşavirin bürosunda }\end{array}$ & 68 & 3,48 & & & \\
\hline \multirow[b]{2}{*}{ Teorik Bilgi Yeterliliği (TBY) } & İşletme içinde, muhasebe servisinde & 48 & 3,15 & \multirow[b]{2}{*}{$-1,032$} & \multirow[b]{2}{*}{114} & \multirow[b]{2}{*}{0,304} \\
\hline & $\begin{array}{l}\text { İşletme dişında, serbest muhasebeci mali } \\
\text { müşavirin bürosunda }\end{array}$ & 68 & 3,35 & & & \\
\hline
\end{tabular}

Yapılan analizler sonucunda muhasebe kayıtlarının tutulduğu yere göre muhasebe çalışanlarının yeterlilikleri arasında anlamlı bir farklılık görülmemiştir $(\mathrm{p}>0,05)$. Bu bilgiler doğrultusunda $\mathrm{H}_{3}$ ve $\mathrm{H}_{4}$ hipotezi reddedilmiştir.

\section{SONUC}

Muhasebe, işletme içi ve işletme dişındaki paydaşlara güvenilir ve objektif bilgileri sunmakla yükümlüdür. $\mathrm{Bu}$ bakımdan muhasebe departmanı çalışanlarının yeterliliği büyük bir önem taşımaktadır. Gelişen teknoloji ile birlikte işletmeler muhasebe meslek mensuplarının teknik olarak yetkin olmalarının yanı sıra başka niteliklere de sahip olmalarını beklemektedir. Gerek Türkiye'de gerekse de diğer ülkelerde bu durumun işletme ve ekonomi üzerindeki etkileri göz önüne alındığında, konu ile ilgili daha fazla araştırmalar yapılmasının önemi kolayca anlaşılmaktadır. Ancak özellikle Türkiye de, konaklama ve yiyecek-içecek işletmeleri muhasebe çalışanları üzerinde yeterli çalışma yapılmadığı görülmektedir. $\mathrm{Bu}$ açığı gidermeye katkıda bulunmak üzere gerçekleştirilen bu araştırmada konaklama ve yiyecek-içecek işletmeleri muhasebe çalışanlarının yeterlilik düzeyleri üzerine odaklanılmıştır. Bu araştırmadan elde edilen sonuçlar aşağıda detaylı olarak gösterilmiştir.

Gerçekleştirilen bu araştırmada, "raporlama ve analiz yeterliliği, teorik bilgi yeterliliği ve turizm muhasebesi yeterliği" olmak üzere 3 faktör olduğu görülmüştür. Bu üç faktörün ortalamalarına bakıldığında; turizm muhasebesi yeterliliğinin $(\bar{x}=3,43 \pm 0,81)$ en yüksek ortalamaya sahip olduğu görülmüştür (Bkz. Tablo 5). Buna göre konaklama ve yiyecek-içecek işletmelerinde muhasebe çalışanlarının kendi alanlarına daha fazla hâkim olduğunu söylemek mümkündür. 
Araştırma sonuçlarında dikkat çeken bir diğer bulgu ise teorik bilgi yeterliliğinin $(\bar{x}=3,27 \pm 0,02)$ daha düşük bir ortalamaya sahip olmasıdır. (Bkz. Tablo 5). Son yıllarda yaşanan değişimler dikkate alındığında muhasebe uygulamalarında teorik bilginin yanı sıra yazılım programlarının kullanmasını gerekli kılmaktadır. Bu noktada muhasebe çalışanlarının teoriyi daha fazla benimseyip uygulamaları önerilmektedir. Diğer taraftan raporlama ve analiz yeterliliğinin $(\bar{x}=2,98 \pm 0,88)$ şeklinde en düşük ortalamaya sahip olduğu görülmüştür (Bkz. Tablo 5).

Araştırma sonuçlarından dikkat çeken diğer bir önemli bulgu, konaklama ve yiyecek-içecek işletmeleri muhasebe çalışanları arasında "raporlama ve analiz yeterliliği, teorik bilgi yeterliliği ve turizm muhasebesi yeterliğì" açısından anlamlı bir farklılı̆̆ın olmamasıdır (Bkz. Tablo 6). Bu noktada konaklama ve yiyecek-içecek işletmeleri muhasebe çalışanlarının raporlama ve analiz yeterliliği, teorik bilgi yeterliliği ve turizm muhasebesi yeterliliği düzeylerinin aynı olduğunu söylemek mümkündür. $\mathrm{Bu}$ durum konaklama ve yiyecek-içecek işletmelerinin muhasebe yapısının benzer olmasından kaynaklandığı düşünülmektedir.

\section{ÖNERILER}

Konaklama işletmeleri muhasebe kayıtlarını oluştururken, diğer departmanlarla ortak otel otomasyon sistemlerini kullanmakta ve bu noktada muhasebecilerin bu sistemlere hâkim olamamasından dolayı sorun yaşadığı düşünülmektedir. Dolayısıyla konaklama işletmeleri muhasebe çalışanlarının bu otomasyon sistemlerini aktif bir şekilde kullanabilmesi gerekmektedir. Bununla birlikte konaklama işletmeleri bilindiği üzere aynı zamanda yiyecek-içecek hizmeti de sunmaktadır. Dolayısıyla bu işlemlerin hepsinin bir arada olması muhasebe işlemlerini daha da karmaşık hale getirmektedir. Bu noktada konaklama işletmeleri muhasebe çalışanlarının yiyecek-içecek işletmelerine kıyasla daha etkin olmasını gerekli kılmaktadır.

Muhasebe çalışanlarının yeterliliğini artırabilecek önemli hususlardan biri de teorik bilgiler 1şığında uygulamaya yönelik muhasebe eğitim süreçlerinin artırılmasına önem verilmelidir. Bununla beraber muhasebe meslek mensupları, mesleki yeterliliklerini artırmak için mali mevzuat süreçlerini de sürekli takip etmelidir.

Gerçekleştirilen bu araştırma sonucunda konaklama ve yiyecek-içecek işletmeleri muhasebe çalışanlarının yeterlilik düzeylerinin bir anlamda fotoğrafı çekilmiştir. Elde edilen sonuçların genel bir eğilim olup olmadığı konuyla ilgili yapılacak diğer çalışma sonuçlarına bakılarak değerlendirilmelidir. Dolayısıyla, daha farklı katılımcılar ile çalışmanın tekrar edilmesi halinde farklı sonuçlar elde edilebilir. Bununla birlikte gelecekte yapılacak çalışmalarda araştırmacılar modele yeni değişkenler ekleyerek muhasebe çalışanlarının yeterliliğini daha iyi açıklayacak bir model geliştirebilirler.

\section{KAYNAKÇA}

ALTIN, M. (2009). Muhasebe Eğitiminin İşletme Beklentilerini Karşılama Düzeyinin Ölçülmesi ve Değerlendirilmesi, Yüksek Lisans Tezi, Niğde: Niğde Üniversitesi Sosyal Bilimler Enstitüsü.

BARTH, M. E. (2008). "Global financialreporting: Implicationsfor US academics", The Accounting Review, 83(5): 1159-1179.

BIYYAN, Özgür (2012). "Muhasebe Meslek Mensuplarına Yönelik Bir Çalışma: Meslek Mensuplarının Demografik Durumları, Mesleki Sorunları ve Değerlendirmesi”, Sosyo Ekonomi Dergisi, S. 2012-1: 105-134.

DALĞAR, H., ÇELIK, İ. ve MORTAŞ, M. (2011). "Muhasebe Öğrenimi Gören Öğrencilerin TMS/TFRS Hakkındaki Farkındalıklarına Yönelik Bir Araştırma", Süleyman Demirel Üniversitesi İktisadi ve İdari Bilimler Fakültesi Dergisi, 16,(1): 217-230.

DEMIR, B. (2012). "Muhasebeye Yön Veren Gelişmeler ve Meslek Yüksekokullarında Verilen Muhasebe Eğitimine Yansımaları", Eğitim ve Öğretim Araştırmaları Dergisi, 1(4): 109-120. 
GENÇTÜRK, M., DEMIR, Y. ve ÇARIKÇI, Ö. (2008). "Meslek Yüksekokulu Öğrencilerinin Muhasebe-Finans Eğitimine Bakış Açıları ve Farkındalıkları Üzerine Bir Uygulama", Süleyman Demirel Üniversitesi İktisadi ve İdari Bilimler Fakültesi Dergisi, 13(1): 209-228.

HATUNOĞLU, Z., UÇAKTÜRK, M. ve KILLI, M. (2013). "Türkiye Finansal Raporlama Standartları'nın Bilinirlik Düzeyi Üzerine Kahramanmaraş’ta Bir Alan Çalışması”, Niğde Üniversitesi İktisadi ve İdari Bilimler Fakültesi Dergisi, 6(1): 51-62.

JACKSON, D. ve CHAPMAN, E. (2012). "Empirically Derived Competency Profiles for Australian Business Graduates and Their Implications for İndustry and Business Schools", The International Journal of Management Education, 10(2): 112-128.

KARAKAYA DEMIRKUTLU, F. (2014). "İşletme Lisans Öğrencilerinin Türkiye Muhasebe/Finansal Raporlama Standartları Hakkındaki İlgi Düzeyleri, Beklentileri Ve Farkındalıkları: Gazi Üniversitesi İktisadi Ve İdari Bilimler Fakültesi Örneği”, İktisadi ve İdari Bilimler Fakültesi Dergisi, 16(2): 156-174.

KILLI, Z. ve HATUNOĞLU, M. (2014). "Hastane İșletmelerinin İstihdam Ettikleri Muhasebe Elemanlarında Aradıkları Nitelikler ve Muhasebe Eğitiminden Beklentileri: Kahramanmaraş, Gaziantep ve Osmaniye İllerinde Bir Alan Çalışması”, Niğde Üniversitesi İktisadi ve İdari Bilimler Fakültesi Dergisi, 7(1): 228-241.

KOZAK, M. A. (Ed.). (2012). Otel İşletmeciliği, Ankara: Detay Yayıncılık.

KUTLUK, F. A., DÖNMEZ, A., UTKU, B. D. ve ERDOĞAN, M. (2012). "Expectation of Accounting Professionals from Accounting Education: An Antalya Research", ProcediaSocialand Behavioral Sciences, S. 62: 418-423.

MCMANUS, L. (2013). "Customer Accounting and Marketing Performance Measures in the Hotel İndustry: Evidence From Australia”, International Journal of Hospitality Management, S. 33: 140- 152.

ÖZSÖZGÜN ÇALIŞKAN, A. (2014). "How Accounting and Accountants may Contribute in Sustainability?", Social Responsibility Journal, 10(2): 246-267.

SUNDER, S. (2010). "Adverse Effects of Uniform Written Reporting Standards on Accounting Practice, Education, and Research”. Journal of Accounting and Public Policy, 29(2): 99-114.

PARKER, L. D. (2002). Reinventing the Management Accountant, Transcript of CIMA Address Delivered at Glasgow University, 15.

PENAFORT, F. ve Bintiahmad, B. (1997). "Employers' Expectations on Today's Accounting Profession: A Malaysian Case-Study", AsianReview of Accounting, 5(2): 78-97.

UYAR, S. ve YELGEN, E. (2012). "Konaklama İşletmelerinin Muhasebe Eğitiminden Beklentileri”, Trakya University Journal of Social Science, 14(2): 327-348.

ÜNAL, O. (2013). "Bankac1lı Sektörünün Muhasebe Eğitiminden Beklentileri”, İşletme Araştırmaları Dergisi, 5(3): 210-225.

ÜNAL, O. ve DOĞANAY, M. (2009). "Lisans Düzeyindeki Muhasebe Eğitiminin Etkinliği: Sayıştay Özelinde Ampirik Bir Çalişma", Sayıştay Dergisi, S.74-75: 117-138.

YARDIM, Ersin (2009). Ortaöğretimde Muhasebe Eğitiminin MEGEP İle Yeniden Yapılandırılması Sonrası Öğrenci Ve İşveren Memnuniyetinin İncelenmesi, Yüksek Lisans Tezi, Kütahya: Dumlupınar Üniversitesi Sosyal Bilimler Enstitüsü.

YILDIZ, F. ve DURAK, G. (2011). "Üniversitelerde Verilen Muhasebe Eğitiminin Kurklareli Yöresinde Faaliyet Gösteren Küçük ve Orta Büyüklükteki İşletmelerin Beklentilerini Karşılama Düzeyinin İncelenmesi”, Muhasebe ve Finansman Dergisi, S. 49: 37-47. 
YÜCENURŞEN, M., BEZIRCİ, M., ÖZPEYNIRCİ, R. ve PEKER, A. A. (2016). "Muhasebe eğitimi ve Kalite Boyutları: Türkiye Alan Araştırması", International Journal of Human Sciences, 13(1): 296-308.

YÜREKLİ, E. ve GÖNEN, S. (2015). "Muhasebe Mensuplarının Nitelikli Meslek Mensubu Yetiştirilmesine Yönelik Önlisans Programından Beklentileri”, Kafkas University. Faculty of Economics and Administrative Sciences Journal, 6(10): 301-316. 